\title{
Trace Element Levels in Native Plant Species around the Industrial Site of Puchuncaví-Ventanas (Central Chile): Evaluation of the Phytoremediation Potential
}

\author{
Soroush Salmani-Ghabeshi ${ }^{1}$, Ximena Fadic-Ruiz ${ }^{2, *}$, Conrado Miró-Rodríguez ${ }^{3} \mathbb{D}$, Eduardo Pinilla-Gil ${ }^{4}$ (D) and \\ Francisco Cereceda-Balic $2,5, *$
}

1 Departamento de Química Analítica, Universidad de Extremadura, ALS-Geochemistry IDA Business Park, Dublin Road Loughrea Galway, H62 PN80 Dublin, Ireland; soroush.zoroaster@gmail.com

2 Centre for Environmental Technologies, Universidad Técnica Federico Santa María, Av. España, Valparaíso 1680, Chile

3 Departamento de Física Aplicada, Universidad de Extremadura, Avda. de la Universidad s/n, E-10071 Cáceres, Spain; cmiro@unex.es

4 Departamento de Química Analítica, Universidad de Extremadura, Avda. de Elvas, s/n, E-06006 Badajoz, Spain; epinilla@unex.es

5 Departamento de Química, Universidad Técnica Federico Santa María, Av. España, Valparaíso 1680, Chile

* Correspondence: ximena.fadic@usm.cl (X.F.-R.); francisco.cereceda@usm.cl (F.C.-B.); Tel.: +56-32-265-4875 (X.F.-R. \& F.C.-B.)

check for updates

Citation: Salmani-Ghabeshi, S.; Fadic-Ruiz, X.; Miró-Rodríguez, C.; Pinilla-Gil, E.; Cereceda-Balic, F. Trace Element Levels in Native Plant Species around the Industrial Site of Puchuncaví-Ventanas (Central Chile): Evaluation of the Phytoremediation Potential. Appl. Sci. 2021, 11, 713. https://doi.org/10.3390/app11020713

Received: 2 December 2020 Accepted: 10 January 2021 Published: 13 January 2021

Publisher's Note: MDPI stays neutral with regard to jurisdictional clai$\mathrm{ms}$ in published maps and institutional affiliations.

Copyright: (C) 2021 by the authors. Licensee MDPI, Basel, Switzerland. This article is an open access article distributed under the terms and conditions of the Creative Commons Attribution (CC BY) license (https:// creativecommons.org/licenses/by/ $4.0 /)$.

\begin{abstract}
The present work investigates the uptake of selected trace elements $(\mathrm{Cu}, \mathrm{Sb}, \mathrm{As}, \mathrm{Pb}, \mathrm{Cd}, \mathrm{Zn}$, $\mathrm{Cr}, \mathrm{Mn}, \mathrm{Ni}, \mathrm{V}$, and $\mathrm{Co}$ ) from soil and their accumulation in the biomass samples (leaves and flowers) of three selected native plants (namely Oenothera picensis, OP; Sphaeralcea velutina, SV; and Argemone subfusiformis, AS) around an industrial area (Puchuncaví-Ventanas) located in the Puchuncaví valley, in the central region of Chile. Primary emission sources in the area come from a copper refinery, coalfired power plants, and a set of 14 other different industrial facilities. Trace element measurements in the native plants of this area and the ability to transfer of these pollutants from soil to plants (transfer factor) have been assessed in order to identify the potential use of these plant species for phytoremediation. Preliminary results showed a high concentration of trace elements in the OP, SV, and AS samples. The concentration of these elements in the plants was found to be inversely correlated to the distance of the primary emission sources. Moreover, the high concentrations of trace elements such as $\mathrm{Cu}, \mathrm{As}, \mathrm{Cr}$ and $\mathrm{V}$, upon the toxic limits in the native plant species, suggest the need for continuous monitoring of the region. The OP species was identified as the plant with the highest capacity for trace elements accumulation, which also showed higher accumulation potential in whole aerial parts than in leaves. Transfer factor values suggested that these native plants had phytoremediation potential for the elements $\mathrm{Cu}, \mathrm{Pb}, \mathrm{As}, \mathrm{Ni}$, and $\mathrm{Cr}$. This study provides preliminary baseline information on the trace element compositions of important native plants and soil in the Puchuncaví-Ventanas area for phytoremediation purposes.
\end{abstract}

Keywords: plant species; industrial pollution; trace elements; transfer factor; phytoremediation

\section{Introduction}

Nowadays, trace metals and other trace elements are known as one of the most critical environmental issues with harmful effects on both human and biophysical environments. They may come from atmospheric and terrestrial sources. Different anthropogenic activities such as mining, ignition of fossil fuels, metalworking industries, and transport traffic can increase the levels of trace metals and other trace elements in natural matrices such as air, water, and soil [1].

Biomonitoring is an excellent and low-cost approach to monitor pollutants in soil, providing an insight into the influence of anthropogenic factors on soil-plant interactions. 
As a result, the use of plants (or their component structures such as stems, roots, and/or leaves) as indicators and monitors of pollution, especially in soil and air, has become more widespread nowadays [2]. Some of the essential advantages inherent to this method include the ample availability of biological material, ease of species identification, sampling and treatment, and ubiquity of some genera, which facilitates covering large areas [3].

Exclusion and accumulation are two ways that plants can tackle high levels of elemental pollutants [4]. As mentioned by Mganga et al. [5], there are three kinds of plant-soil relationships: excluder, accumulator, and indicator plants. Excluder plants are plants that limit the transport of pollutants to external parts and keep the concentration of them in shoots stable over a wide range of metals in the soil. Nevertheless, they can still contain considerable amounts of metals in their roots. Accumulators are plants with the tendency and ability to accumulate high amounts of metals in their external parts. Finally, indicator plants accumulate metals in their external parts, and normally, the level of metals in their tissues is a reflection of the level of metals in the soil.

There are different physical and chemical methods to clean up elemental pollutants from the soil. However, usually, these techniques are economically and environmentally expensive, and furthermore, they can have harmful effects on soil structure (physical, chemical, and biological) [1]. In the phytoremediation technique, roots absorb pollutants from the soil and transfer them to the shoots and other external parts of the plants without showing any stress symptoms [6]. Therefore, knowing the characteristics of the transfer of trace elements from soil to plants (transfer factor) is essential [7]. In this sense, transfer factor values depend on different factors. Thus, transfer factors can vary according to the location, since different locations can have different soil nutrients, $\mathrm{pH}$, organic matter, and clay contents, and they can also differ between plant species [8].

Small-size and slow-growing plants are mostly tolerant and accumulator species, which limits their applicability for phytoremediation purposes. Thus, nowadays, fastgrowing plants and trees are more used for phytoremediation, even when they are not hyperaccumulators [1]. With this fact, polluted areas can be considered as a storage of native plants with the ability to accumulate elemental pollutants into their external parts [9].

Puchuncaví-Ventanas is one of the main industrial areas of Chile, which comprises a wide range of industrial factories and activities (such as copper smelter and coal-fired power plants), implying potential risks to human and environmental health in terms of elemental pollutants [10]. Previous studies in plants around the industrial site of Puchuncaví-Ventanas were focused on a limited number of elemental pollutants (mainly copper), even though a wide variety of them usually contaminate this industrial complex (IC). The investigation of the influence of anthropogenic pollution by trace elements from the IC on the local vegetation of this area begins with the study of Ginocchio [11], who investigated the effects of the copper smelter plant on local vegetation and grassland in the industrial Puchuncaví valley. Grassland was quantitatively analyzed in terms of the physicochemical properties of soil, the multitude and diversity of plant species, and the soil seed bank. This work pointed out that a decrease in total soil nitrogen could explain $13 \%$ of the changes detected in plant abundance, while soil $\mathrm{pH}$ and $0.05 \mathrm{M}$ Ethylene diamine tetraacetic acid (EDTA) extractable copper explained $10 \%$ and $7 \%$, respectively. Furthermore, it was found that this pollution had affected the regeneration ability of the native plant species from the soil seed bank and the seed distribution in the soil [11]. For instance, González et al. [12] determined copper concentrations in 22 different native species near the Ventanas smelter in order to compare copper concentration levels (200 and $600 \mathrm{mg} \mathrm{kg}^{-1}$ ) in these species, aiming at identifying the hyperaccumulator plants representative of Chilean conditions. Although no hyperaccumulator native plants were found, Oenothera picensis (treated as Oenothera affinis [12], hereinafter referred to as Oenothera picensis [13]) was considered a good candidate for remediation initiatives in this area [12]. Moreover, De Gregory et al. [14] monitored copper (9.3 and $\left.8.6 \mathrm{mg} \mathrm{kg}^{-1}\right)$ and selenium $\left(0.1\right.$ and $\left.0.4 \mathrm{mg} \mathrm{kg}^{-1}\right)$ concentrations in rainwater, soils, and Medicago sativa samples at various sites from three different zones of the Valparaíso region, including the Puchuncaví valley. In this case, a close correlation 
between copper concentrations in soil and Medicago sativa samples was found as a function of the distance from the smelter [14]. Staying focused on phytoremediation purposes of Puchuncaví valley, Meier et al. [15] studied the low molecular weight organic acid (LMWOA) root exudation pattern and $\mathrm{Cu}$ accumulation capability in the shoot and root tissues of two native Chilean metallophytes (O. affinis and Imperata condensata) and two agricultural plants (Lupinus albus and Helianthus annus). These plants were grown under hydroponics conditions at increasing copper levels and analyzed after harvesting. All the plant species showed high $\mathrm{Cu}$ accumulation, among which the metallophyte $\mathrm{O}$. affinis was found to be the most tolerant species (116 and $2657 \mathrm{mg} \mathrm{kg}^{-1} \mathrm{Cu}$ in shoots and roots, respectively). Additionally, they stated that the LMWOA root exudation is a crucial $\mathrm{Cu}$ tolerance mechanism developed by metallophytes that should be considered as an important factor for plant selection in phytoremediation programs [15]. Regarding the O. picensis species, further studies were carried out by Muena et al. [16] to evaluate the effects of liming and nitrogen fertilization on its cotyledon emergence, survival, biomass production, and copper accumulation. In this case, O. picensis (named O. affinis in this work) was grown in soil from Puchuncaví valley, but in controlled conditions. These results showed that liming decreased $\mathrm{Cu}$ concentration and $\mathrm{Cu}^{2+}$ activity in the soil solution, whereas nitrogen fertilization increased the concentration of $\mathrm{Cu}$ in roots and shoots in limed soils. Therefore, they concluded that liming is sufficient to improve soil conditions for the development of $O$. picensis in acid- and metal-contaminated soils, allowing its potential use for phytostabilization [16]. Similarly, González et al. [12] evaluated the effects of the biodegradable chelate of methylglycinediacetic acid (MGDA) on copper extraction by Oenothera picensis species (classified as O. affinis by González et al. [12]) through acid soil samples from Los Maitenes (Puchuncaví valley). In this case, MGDA application, which was added at four different rates, 0 (control), 2, 6 and $10 \mathrm{mmol} \mathrm{plant}^{-1}$, considerably increased biomass production and copper extraction from $0.09 \mathrm{mg} \mathrm{plant}^{-1}$ (control) to

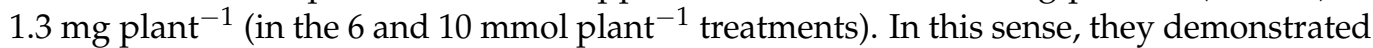
that applications of MGDA are an effective and environmentally safe way to improve copper extraction by $O$. picensis in these soils [13]. Recently, Gorena et al. [2] reported the use of Cupressus macrocarpa leaves as a biomonitor to evaluate the high pollution load for anthropogenic elements in the industrial complex area of Puchuncaví valley (IC), observing a clear trend of increased leaf concentration of $\mathrm{Cu}, \mathrm{Sb}, \mathrm{S}, \mathrm{As}, \mathrm{Cd}$, and $\mathrm{Pb}$ with the proximity to the IC. Besides, high values of $\mathrm{Cu}\left(93.4-369 \mathrm{mg} \mathrm{kg}^{-1}\right)$ and As (7.6-12.7 $\mathrm{mg} \mathrm{kg}^{-1}$ ) were observed near the industrial area, exceeding the phytotoxic levels reported in plants, with enrichment factors $>3000 \%$ for $\mathrm{Cu}$ and $>1300 \%$ for As.

In this context, this study aims to determine 11 trace element concentrations in three native plants species, Oenothera picensis (OP), Sphaeralcea velutina (SV), and Argemone subfusiformis (AS), found in four sampling locations (La Greda, Los Maitenes, Valle Alegre, and Cachagua) sited at a different distance from the industrial affected area of Puchuncaví-Ventanas (Chile). The ability of these native plants to accumulate the selected elements in their higher parts will be further evaluated in order to assess their potential application in the phytoremediation plans of this area.

\section{Materials and Methods}

\subsection{Site Description (Including Vegetation)}

The study took place in the surroundings of the Puchuncaví-Ventanas industrial complex in the coastal area of the Valparaíso region in central Chile. The primary emission sources operating in the complex are a copper smelter and refinery (400,000 metric tons of refined copper per year) [17] and a thermoelectric coal plant (544 MW) [18]. The soil of this zone has received polluted atmospheric deposition since 1964, mainly metal-rich particulate matter and acid rain due to the $\mathrm{SO}_{2}$ emissions from the copper refinery. Since 1999, i.e., after 35 years of production, the emissions were reduced significantly thanks to the incorporation of abatement measures required for entry into force of the new state environmental regulations [19]. As a consequence, the soils around the industrial complex now 
have an acidic $\mathrm{pH}$ and high concentrations of trace metals and other elements [10,11,20-22]. Accordingly, the ecosystems associated with these soils have become seriously degraded and eroded, characterized by a bare and sparse vegetation [11].

Three sampling points were selected for the present study: La Greda (LG) $\left(32^{\circ} 45^{\prime} 14^{\prime \prime}\right.$ S$\left.71^{\circ} 28^{\prime} 17^{\prime \prime} \mathrm{W}\right)$, Los Maitenes (LM) $\left(32^{\circ} 46^{\prime} 20^{\prime \prime} \mathrm{S}-71^{\circ} 28^{\prime} 13^{\prime \prime} \mathrm{W}\right)$, and Valle Alegre (VA) $\left(32^{\circ} 48^{\prime} 27^{\prime \prime} \mathrm{S}-71^{\circ} 26^{\prime} 5^{\prime \prime} \mathrm{W}\right)$, located $1.2 \mathrm{~km} \mathrm{NE}, 1.5 \mathrm{~km} \mathrm{SE}$, and $6.5 \mathrm{~km} \mathrm{SE}$, respectively, from the industrial complex. Additional samples were collected in Cachagua $(\mathrm{CH})\left(32^{\circ} 34^{\prime} 52^{\prime \prime} \mathrm{S}\right.$ $71^{\circ} 26^{\prime} 55^{\prime \prime} \mathrm{W}$ ), located $20.3 \mathrm{~km} \mathrm{~N}$ from Ventanas. These sites were selected according to previous soil contamination records $[10,22]$ that may follow an expected concentration gradient pattern. La Greda and Los Maitenes are the nearest to the emission sources, and therefore, they are expected to be the most impacted sites. In contrast, Valle Alegre is located in an intermediate impact position, and Cachagua is the farthest location northwards and so is nearly unaffected by industrial impact (Figure 1).

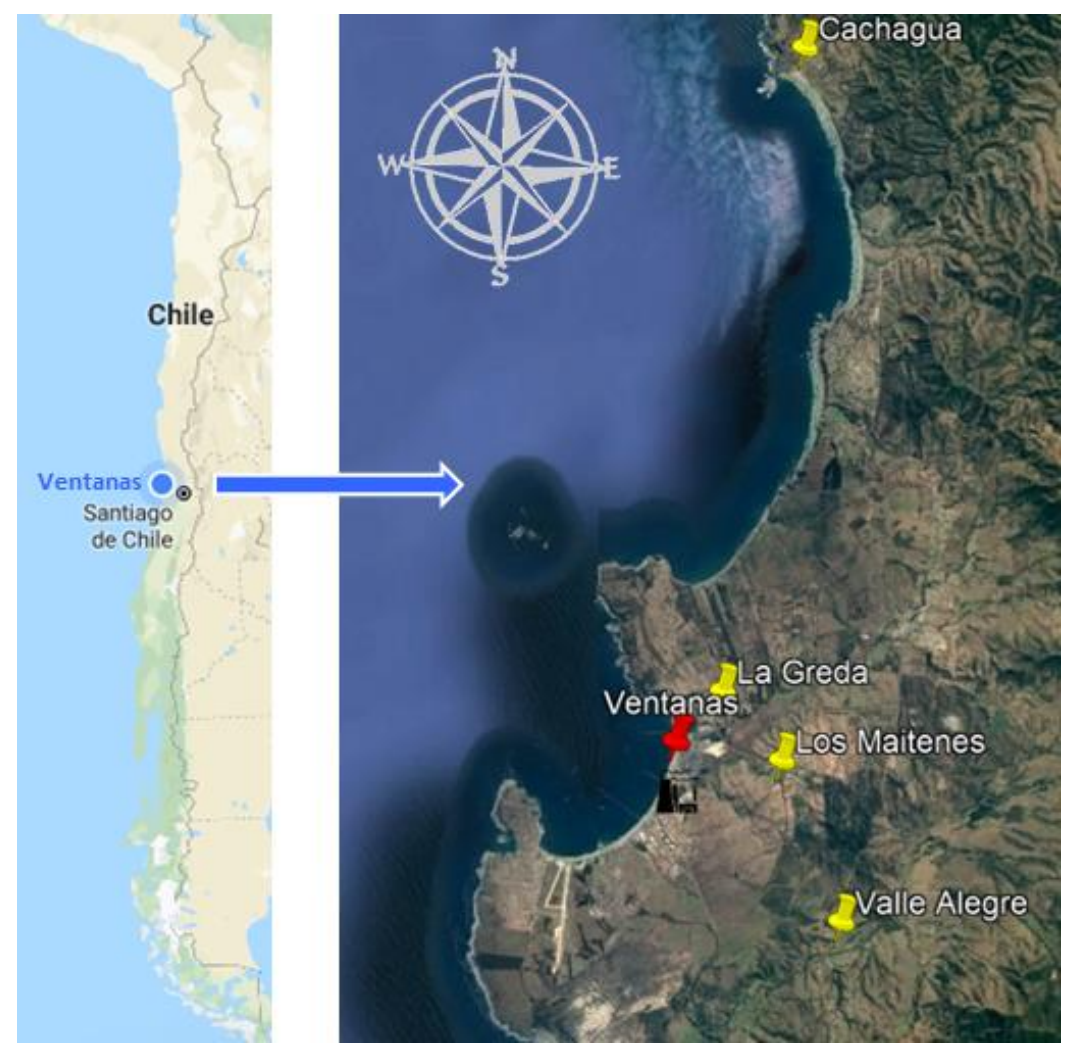

Figure 1. Geographical locations of the monitoring sites according to GPS records.

The vegetation at these sampling sites corresponds to typical Mediterranean ecosystems with a predominance of grassland and bushes [20]. In the study area, especially the zone about $2-3 \mathrm{~km}$ around the emission sources, the vegetation cover decreases gradually until almost disappearing at the bottom of the stack of smelting slag [12].

\subsection{Plant Sampling and Identification}

The plant species selected for the present study were Oenothera picensis (OP), a native biannual herb and hemicryptophyte that grows up to $0.5-0.8 \mathrm{~m}$ tall [12], Sphaeralcea velutina (SV), an endemic small, round, and dense shrub (up to $0.7-\mathrm{m}$ tall) nanophanerophyte plant $[12,20]$, and Argemone subfusiformis (AS), a native annual herb and therophyte that has erect and prickly stems and leaves and reaches up to 0.7-1.2 $\mathrm{m}$ high. O. picensis was previously described as a potential copper metallophyte to survey plant diversity in the Puchuncaví-Ventanas area $[12,13,15]$. They are all drought-resistant with high tolerance to metal contamination and soil acidity [12]. 
All samples were collected in spring according to previous studies [23,24], on the same day at each sampling point, to maximize the comparability of the results. However, a different number of species was collected at each location according to their natural availability. That is, in LM, three plant species (one composite sample from each species) were collected. Meanwhile, in VA, one composite sample of AS was collected, and one composite sample of OP in LG. Finally, in CH (reference area), two composite samples corresponding to OP and SV species (one of each) were selected.

Soil samples were taken around each site of plant sampling according to a previously described protocol [10].

\subsection{Reagents}

All chemicals used for the preparation of stock and standard solutions were of analytical grade. Inductively coupled plasma (ICP) multielement standard solutions were obtained from PerkinElmer (Waltham, MA, USA) and Panreac (Spain). Working solutions were prepared by dilution with ultra-pure water (resistivity $>12 \mathrm{M} \Omega$ ) obtained from an ultramatic system (Wasserlab, Spain).

Hiperpure-Plus $\mathrm{HCl}(35 \%)$ and $\mathrm{HF}$ (48\%) (Parneac, Spain) were used for plant digestion. Dilute standards and digested solutions from real samples and reference material were adjusted to the desired $\mathrm{pH}$ with sub-boiled $\mathrm{HNO}_{3}(69 \% \mathrm{w} / \mathrm{w})$ obtained from a quartz sub-boiling system (Kürner, Rosenheim, Germany). Furthermore, $10 \mu \mathrm{g} \mathrm{L}^{-1} \mathrm{Ge}$ (II) and In (III) standards (Parneac, Spain) were used as internal standards. Standard Reference Material ${ }^{\circledR} 1573$ a tomato leaves from the U.S. National Institute of Standards and Technology (NIST 1573a) and rye grass No. 281 from the Community Bureau of Reference (BCR 281) were used for accuracy testing.

\subsection{Plant and Soil Analysis}

After field collection, all samples were carefully washed (twice) with tap water and further with distilled water (twice) to remove soil particles. Subsequently, the samples were left to dry on a lab bench at room temperature and then dried for $48 \mathrm{~h}$ at $40{ }^{\circ} \mathrm{C}$ on a stove. After drying, leaves and flowers were picked from the main branches. Finally, leaves and flowers were manually triturated and individually placed into polyethylene bags until analysis.

Plant sub-samples were mechanically homogenized in an agate planetary ball mill and manually sieved through a $0.2-\mathrm{mm}$ polyethylene mesh. A microwave system (MARS-X 1200 W Microwave Accelerated Reaction System, CEM, Mathews, NC, USA) was used for sample digestion following the methodology described by Wiseman et al. [25]. Briefly, $150 \mathrm{mg}$ of real sample (a mixture of flowers and leaves and only leaves) and $300 \mathrm{mg}$ of reference material were weighed and placed into Teflon digestion vessels. Afterwards, samples were pre-digested overnight with $4.5 \mathrm{~mL} \mathrm{HNO}_{3}$ and $1.5 \mathrm{~mL} \mathrm{HCL}\left(9 \mathrm{~mL} \mathrm{HNO}_{3}\right.$ and $3 \mathrm{~mL} \mathrm{HCL}$ for reference material samples). Pre-digested samples were then filtered 2 or 3 times before digestion in a microwave at $160{ }^{\circ} \mathrm{C}(600 \mathrm{~W}$, ramp time $15 \mathrm{~min}$, and $15 \mathrm{~min}$ holding time). Then, samples were evaporated on a heater at $95{ }^{\circ} \mathrm{C}$ until near dryness. Additionally, $0.5 \mathrm{~mL}$ of concentrated $\mathrm{HF}$ was added to the real samples $(1 \mathrm{~mL}$ for reference material samples) to remove silicates, and the samples were heated until they almost dried. After that, $1 \mathrm{~mL}$ of concentrated $\mathrm{HNO}_{3}$ was added to the real samples $(2 \mathrm{~mL}$ for reference material samples), and they were evaporated until near dryness. This last step was repeated twice. Finally, the real samples were diluted to a total volume of $10 \mathrm{~mL} \mathrm{HNO}_{3}$ $(5 \% v / v)$, whereas reference material samples were brought up to a total volume of $50 \mathrm{~mL}$.

The digested samples were analyzed using ICP-MS equipment (PerkinElmer ELAN 9000). The instrumental settings were RF power $1000 \mathrm{~W}$, plasma gas flow rate $1 \mathrm{~L}$ of argon $\min ^{-1}$, and $35 \mathrm{~s}$ washing time. Furthermore, $50 \mu \mathrm{L}$ of a solution containing In (III) and Ge (II) (10 mg L $\left.{ }^{-1}\right)$ was used as an internal standard. Each sample was assayed in triplicate. 
Soil samples were assayed according to a previously described protocol based on acid digestion and ICP-MS measurement [10].

\subsection{Quality Assurance/Quality Control}

Acid blanks were run with all sample series for quality control without measuring significant concentrations of the studied elements.

NIST 1573a (tomato leaves) and BCR 281 (rye grass) were assayed to ensure the reliability of results and to validate the method performance. The results obtained (Table 1 ) show that all samples have percentage recoveries between $80 \%$ and $130 \%$ for NIST 1573a (tomato leaves) and $75 \%$ and $130 \%$ for BCR 281 (rye grass), except for some elements (As and $\mathrm{Sb}$ ) due to an ICP-MS overestimation. A more advanced ICP-MS instrument would be desirable for the quantification of these elements. Nevertheless, the relative standard deviation remains under $12 \%$, except for Co $(26.3 \%)$, allowing to apply correction factors to $\mathrm{As}$ and $\mathrm{Sb}$ concentration if necessary. These accuracy and precision results confirmed that the analytical methodology is appropriate for the analytes selected, at least in the context of a preliminary study to identify the main features of potential phytoremediation species in the Puchuncaví area.

Table 1. Results summary for the standard reference materials National Institute of Standards and Technology (NIST) 1573a (tomato leaves) and Community Bureau of Reference (BCR) 281 (rye grass).

\begin{tabular}{|c|c|c|c|}
\hline Elements & SRM & Certified Values $\left(\mathrm{mg} \mathrm{kg}^{-1}\right) \pm \mathrm{SD}$ & Measured Concentration $\left(\mathrm{mg} \mathrm{kg}^{-1}\right) \pm \mathrm{SD}$ \\
\hline $\mathrm{Cr}$ & NIST 1573a & $1.99 \pm 0.06$ & $1.44 \pm 0.13$ \\
\hline Mn & $\begin{array}{c}\text { NIST 1573a } \\
\text { BCR } 281\end{array}$ & $\begin{array}{c}246 \pm 8 \\
81.6 \pm 2.6\end{array}$ & $\begin{array}{c}199 \pm 12 \\
62.6 \pm 0.1\end{array}$ \\
\hline $\mathrm{Ni}$ & $\begin{array}{c}\text { NIST 1573a } \\
\text { BCR } 281\end{array}$ & $\begin{array}{l}1.59 \pm 0.07 \\
3.00 \pm 0.17\end{array}$ & $\begin{array}{c}1.74 \pm 0.12 \\
2.25 \pm 0.003\end{array}$ \\
\hline $\mathrm{Cu}$ & $\begin{array}{c}\text { NIST 1573a } \\
\text { BCR } 281\end{array}$ & $\begin{array}{l}4.70 \pm 0.14 \\
9.65 \pm 0.68\end{array}$ & $\begin{array}{l}4.03 \pm 0.25 \\
9.17 \pm 0.02\end{array}$ \\
\hline $\mathrm{Zn}$ & NIST $1573 a$ & $30.9 \pm 0.7$ & $35.5 \pm 3.08$ \\
\hline As & $\begin{array}{c}\text { NIST 1573a } \\
\text { BCR } 281\end{array}$ & $\begin{array}{l}0.112 \pm 0.004 \\
0.057 \pm 0.004\end{array}$ & $\begin{array}{c}0.24 \pm 0.03 \\
0.095 \pm 0.00\end{array}$ \\
\hline $\mathrm{Cd}$ & $\begin{array}{c}\text { NIST 1573a } \\
\text { BCR } 281\end{array}$ & $\begin{aligned} 1.52 & \pm 0.04 \\
0.120 & \pm 0.003\end{aligned}$ & $\begin{array}{c}1.77 \pm 0.20 \\
0.165 \pm 0.000\end{array}$ \\
\hline $\mathrm{Pb}$ & BCR 281 & $2.38 \pm 0.11$ & $2.71 \pm 0.00$ \\
\hline $\mathrm{Sb}$ & $\begin{array}{l}\text { NIST 1573a } \\
\text { BCR } 281\end{array}$ & $\begin{array}{l}0.063 \pm 0.006 \\
0.047 \pm 0.005\end{array}$ & $\begin{array}{l}0.088 \pm 0.008 \\
0.062 \pm 0.000\end{array}$ \\
\hline $\mathrm{V}$ & NIST 1573a & $0.835 \pm 0.01$ & $0.879 \pm 0.05$ \\
\hline Co & NIST 1573a & $0.57 \pm 0.02$ & $0.38 \pm 0.10$ \\
\hline
\end{tabular}

\subsection{Transfer Factor Calculations}

Transfer factor (TF) was calculated according to the following equation [26-28]:

$$
\mathrm{TF}=\text { Cplant } / \text { Csoil }
$$

where Cplant is the element concentration in the plant tissue $\left(\mathrm{mg} \mathrm{kg}^{-1}\right)$ and Csoil is the element concentration in the soil $\left(\mathrm{mg} \mathrm{kg}^{-1}\right)$. The results are categorized based on their TF into low (less than 0.09), medium (0.10-0.99), and high ( $>1.0)$ levels. Besides, TF $>1$ indicates enrichment of the element in the plant [27]. 


\section{Results and Discussion}

\subsection{Trace Elements Concentrations in Plant Species}

All of the collected plants were assayed for trace element concentrations in a mixture of leaves and flower samples, except for O. picensis (OP), for which an additional leaf sample was also collected in La Greda (LG leaves). Table 2 summarizes the results' average and the range of measured concentrations on a dry-weight basis, according to the different species and sampling locations. The values are classified as toxic or non-toxic, and the hyperaccumulation limits for the plants, according to the values reported by Massa et al. [1], are also summarized in Table 2 and Figure 2.

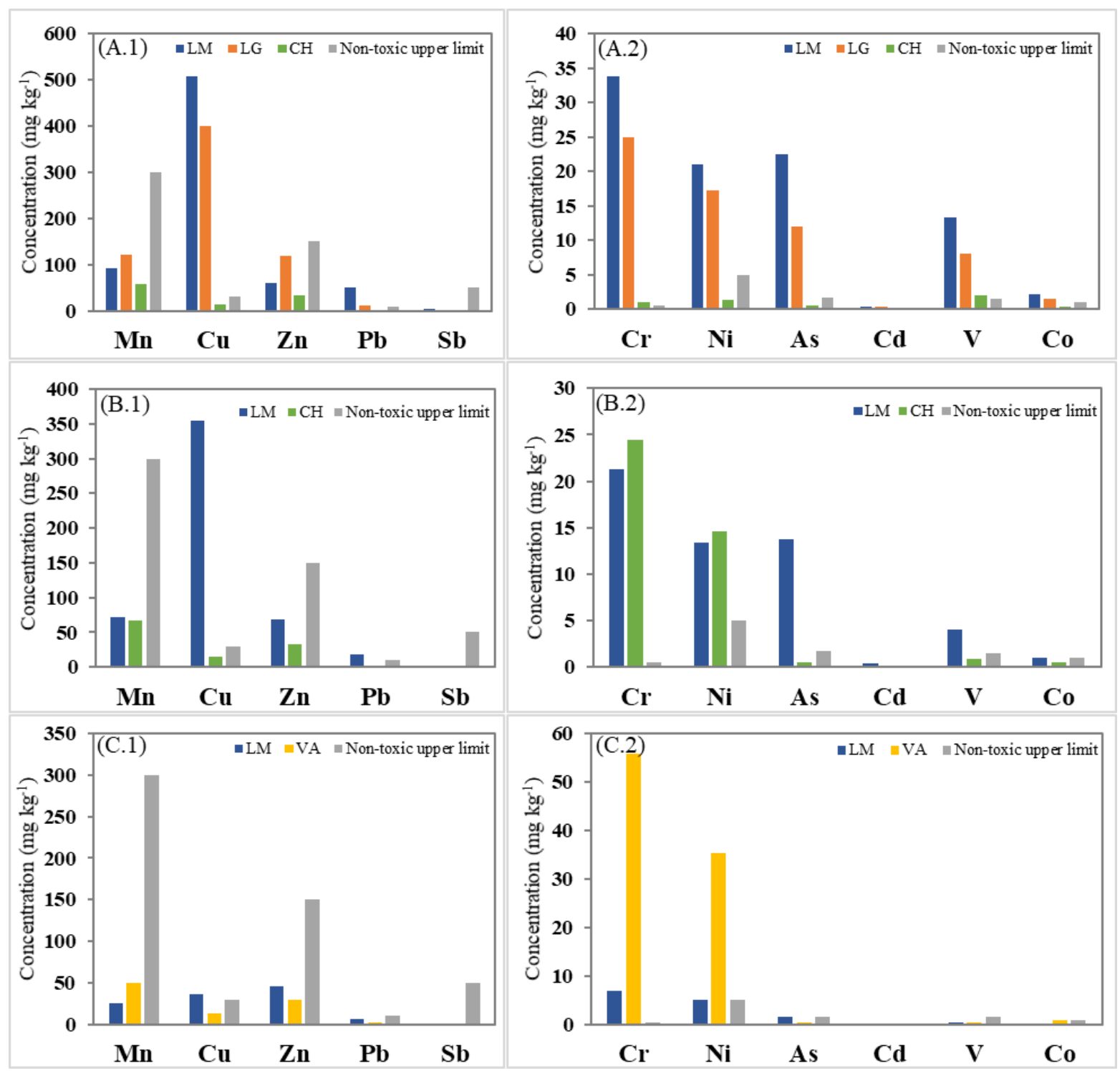

Figure 2. Mean trace element (TE) concentration $\left(\mathrm{mg} \mathrm{kg}^{-1}\right)$ at each sampling location according to the plant species: O. picensis' TEs in major (A.1) and in minor (A.2) concentrations; S. velutina's TEs in major (B.1) and in minor (B.2) concentrations; and A. subfusiformis' TEs in major (C.1) and in minor (C.2) concentrations. 


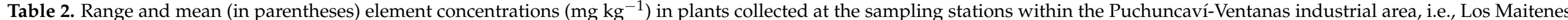

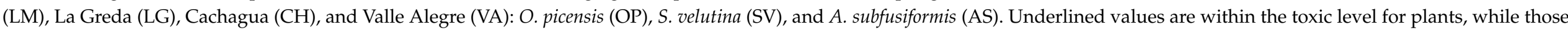
in bold are over the toxic limit.

\begin{tabular}{|c|c|c|c|c|c|c|c|c|c|c|c|c|}
\hline & Elements & $\mathrm{Cr}$ & Mn & $\mathrm{Ni}$ & $\mathrm{Cu}$ & $\mathrm{zn}$ & As & $\mathrm{Cd}$ & $\mathrm{Pb}$ & sb & $\mathrm{v}$ & Co \\
\hline \multirow{3}{*}{ Concentration $\left(\mathrm{mg} \mathrm{kg}^{-1}\right)$} & Non-toxic & $0.1-0.5$ & $30-300$ & $0.1-5$ & 5-30 & $27-150$ & $1-1.7$ & $0.05-0.2$ & $5-10$ & $7-50$ & $0.2-1.5$ & $0.02-1$ \\
\hline & Toxic & $5-30$ & $400-1000$ & $10-100$ & $20-100$ & $100-400$ & $5-20$ & $5-30$ & $30-300$ & 150.00 & $5-10$ & $15-50$ \\
\hline & Hyperaccumulation Limit & 1000 & 10,000 & 1000 & 1000 & 10,000 & - & 100 & 1000 & - & - & 1000 \\
\hline Species & Location & \multicolumn{11}{|c|}{ Concentrations $\left(\mathrm{mg} \mathrm{kg}^{-1}\right)$} \\
\hline \multirow{4}{*}{ O. picensis (OP) } & LM & $30.64-35.46$ (33.77) & 83.67-99.24 (92.34) & 19.70-21.68 (21.00) & $467.92-548.44$ (507.77) & $55.24-66.66(60.35)$ & $20.52-25.17(22.47)$ & $0.36-0.45(0.40)$ & $34.03-78.84(49.64)$ & $3.65-5.07(4.17)$ & $11.78-14.44(13.29)$ & $2.03-2.22(2.11)$ \\
\hline & LG & 23.01-26.16 (24.95) & $114.99-126.46(120.70)$ & $16.26-17.90(17.24)$ & $390.53-407.94(399.41)$ & $115.46-119.26(117.87)$ & $11.42-12.93(12.01)$ & $0.30-0.33(0.31)$ & $11.36-12.73(11.99)$ & $1.60-2.19(1.84)$ & 7.51-8.92(8.15) & $1.38-1.67(1.49)$ \\
\hline & LG (leaves) & $8.99-9.63(9.20)$ & $117.09-127.71(123.66)$ & $9.06-9.83(9.40)$ & $190.34-204.99(196.53)$ & $135.01-142.57(138.84)$ & $3.36-4.03(3.80)$ & $0.27-0.29(0.28)$ & $5.55-6.07(5.80)$ & $0.56-0.64(0.60)$ & $1.23-1.27(1.25)$ & $0.48-0.59(0.52)$ \\
\hline & CH & $0.82-1.27(1.02)$ & $52.71-60.55(56.80)$ & $1.20-1.47(1.30)$ & 12.52-14.99(13.51) & $31.46-35.08(33.34)$ & $0.49-0.64(0.58)$ & $0.03-0.03(0.03)$ & $1.06-1.14(1.11)$ & $0.08-0.09(0.09)$ & $1.83-2.30(2.02)$ & $0.28-0.42(0.35)$ \\
\hline \multirow{2}{*}{ S. velutina (SV) } & LM & $20.73-21.80(21.23)$ & $68.90-73.29(71.56)$ & 12.85-13.97 (13.40) & $347.95-364.70(355.22)$ & $66.54-69.88$ (68.63) & 12.75-14.24 (13.70) & $0.41-0.45(0.43)$ & $17.96-19.10(18.47)$ & $2.05-2.11(2.07)$ & $4.00-4.11(4.06)$ & $1.02-1.11(1.05)$ \\
\hline & $\mathrm{CH}$ & 23.48-25.52 (24.42) & $63.95-70.14(67.05)$ & 14.07-15.07 (14.58) & $14.40-15.43(14.84)$ & $30.92-36.47(33.38)$ & $0.46-0.52(0.49)$ & $0.12-0.13(0.12)$ & $0.82-1.57(1.09)$ & $0.09-0.10(0.10)$ & $0.89-0.92(0.91)$ & $0.41-0.52(0.47)$ \\
\hline \multirow{2}{*}{ A. subfusiformis (AS) } & LM & $6.72-7.10(6.91)$ & $24.33-26.88(25.90)$ & $4.81-5.05(4.97)$ & $33.67-40.02(36.52)$ & $43.40-47.75(45.90)$ & $1.48-1.61(1.52)$ & $0.06-0.09(0.07)$ & $1.99-8.55(6.34)$ & $0.25-0.35(0.28)$ & $0.47-0.51(0.49)$ & $0.13-0.38(0.23)$ \\
\hline & VA & $49.02-63.31(55.72)$ & $47.22-52.03(49.56)$ & $30.16-41.19(35.35)$ & $13.20-14.03(13.75)$ & $27.51-33.16(30.16)$ & $0.26-0.39(0.33)$ & $0.06-0.10(0.08)$ & $0.74-4.20(1.97)$ & $0.06-0.09$ & $0.40-0.42(0.41)$ & $0.82-0.98(0.88$ \\
\hline
\end{tabular}

Note: Toxic concentration levels in mature leaf tissues generalized for various species $\left(\mathrm{mg} \mathrm{kg}^{-1}\right)$ are taken from Massa et al. [1]. 
The concentrations measured showed that no hyperaccumulator plants are present in any location, as reported in previous studies [12]. However, among the three different selected species, $O$. picensis $(\mathrm{OP})$ plants showed the highest concentrations of trace elements in their component structures (leaves and flowers). The average trace element concentrations in this species decreased in the following order (Table 2): $\mathrm{Cu}>\mathrm{Mn}>\mathrm{Zn}>\mathrm{Pb} / \mathrm{Cr}$ for $\mathrm{LM}$ and $\mathrm{LG}$, but $\mathrm{Mn}>\mathrm{Zn}>\mathrm{Cu}>\mathrm{V}$ for $\mathrm{CH}$, following a slightly similar but not identical trend to the corresponding concentrations in the soil samples: $\mathrm{Mn}>\mathrm{Cu}>\mathrm{Zn}>\mathrm{V}$ for LM, but $\mathrm{Cu}>\mathrm{Mn}>\mathrm{Zn}>\mathrm{V}$ for LG and $\mathrm{Mn}>\mathrm{Zn}>\mathrm{V}>\mathrm{Cu}$ for $\mathrm{CH}$ (Table 3). Table 3 summarizes the physicochemical characteristics and trace element levels found in the composite soil samples collected at the sampling locations, and some reference soil quality standards guidelines are also given for comparison. In this species (OP), the highest concentrations were found in Los Maitenes (LM), except for Mn and Zn, whose highest concentrations were reached in La Greda (LG). The difference in the elemental concentrations between these sampling sites is probably related to the soil chemical characteristics and corresponding concentrations in soil samples (Table 3). Thus, near the industrial complex $\mathrm{Cu}, \mathrm{Zn}, \mathrm{As}$, and $\mathrm{Pb}$ soil concentrations were higher in LG than in LM, and consequently, the potential to accumulate these metals by OP species may be more significant at this site. However, interestingly, $\mathrm{OP}$ species tended to accumulate a higher quantity of $\mathrm{Cu}, \mathrm{As}$, and $\mathrm{Pb}$ in $\mathrm{LM}$, even though the concentration of these elements in soil was lower than in LG. This fact may be explained by the different soil characteristics of these locations since the physicochemical properties of the soil also influence the behavior, phytobioavailability, and toxicity of trace elements. In general, several studies demonstrated that TEs' availability is higher in acid soils containing low concentrations of organic matter, such as in LM (0.34\%) [29-31]. Hence, $\mathrm{Cu}$ uptake increases within a $\mathrm{pH}$ range of 5 to 7 , corresponding to LM conditions ( $\mathrm{pH}$ 5.3).

It is also interesting to compare the spatial trend of trace element contents in the selected biomonitors and the content of the same elements in atmospheric deposition, the leading mechanism of transport of pollutants from the nearby industrial sources to the soil and biota in the study area. Our group has reported enrichment of a set of relevant trace elements, including $\mathrm{Mn}, \mathrm{Cu}, \mathrm{As}, \mathrm{Cd}, \mathrm{Pb}, \mathrm{Sb}, \mathrm{V}$, and $\mathrm{Co}$, in both soluble and insoluble fractions of atmospheric deposition [32] in samples collected in the area by a novel filtrating bulk passive sampling device appropriate for on-site measurements [33]. The spatial trend of trace element levels in the atmospheric deposition was similar to the overall trend found in the selected biomonitor samples reported in this work, with higher concentrations in the vicinity of the industrial complex and decreasing concentrations at longer distances and especially upwind. A more detailed study of insoluble atmospheric deposition composition in the area by digestion + ICP-MS, focusing on Al, As, Ba, Cd, Co, $\mathrm{Cu}, \mathrm{Fe}, \mathrm{K}, \mathrm{Mn}, \mathrm{Pb}, \mathrm{Sb}, \mathrm{Ti}, \mathrm{V}$, and $\mathrm{Zn}$, showed a similar trend. This study also allowed to identify industrial, traffic, and mineral-crustal factors by principal component analysis and soil critical loads exceedances by atmospheric deposition of $\mathrm{Pb}$ at all sampling locations in the area affected by the industrial emissions, more significant in La Greda, close to the industrial complex [34].

Regarding the plant toxicity levels, the case of $\mathrm{Cu}$ is especially remarkable, reaching concentration levels 5-25 times higher than the toxic level concentration. Indeed, O. picensis (OP) showed critical trace metal concentrations (above toxicity levels) in LM for $\mathrm{Cr}, \mathrm{Cu}, \mathrm{As}$, and $\mathrm{V}$, whereas $\mathrm{Pb}$ and $\mathrm{Ni}$ levels were also found at toxic concentrations. The prevalence of critical $\mathrm{Cu}$ concentrations in LG suggests that the impact of the copper smelter could be the primary source of these elements in the area.

Even more, both sampling locations (LG and LM) had trace element concentrations much higher than the levels found at the reference site Cachagua $(\mathrm{CH})$, ranging from around $2(\mathrm{Mn})$ to $38(\mathrm{Cu})$ times, which highlights the impact of the industrial activities in the area. The concentration of these elements in the plants was inversely correlated to the distance of the primary emission sources, as observed in other soil studies in the same area [10]. 


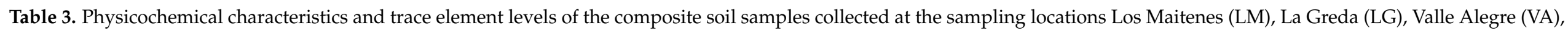
the and reference sampling point at Cachagua $(\mathrm{CH})$. Reference soil quality standards guidelines are also given.

\begin{tabular}{|c|c|c|c|c|c|c|c|c|c|c|c|c|c|c|c|}
\hline \multirow{2}{*}{ Location } & \multirow{2}{*}{$\mathrm{pH}$} & \multirow{2}{*}{ Organic Matter (\%) } & \multirow{2}{*}{ C.E.C ${ }^{*}\left(\right.$ meq $\left.100 \mathrm{~g}^{-1}\right)$} & \multirow{2}{*}{ Sand/Silt/Clay (\%) } & \multicolumn{11}{|c|}{ Mean Concentrations of Element in Soil $\left(\mathrm{mg} \mathrm{kg}^{-1}\right)$} \\
\hline & & & & & $\mathrm{Cr}$ & Mn & $\mathrm{Ni}$ & $\mathrm{Cu}$ & $\mathrm{Zn}$ & As & $\mathrm{Cd}$ & $\mathbf{P b}$ & $\mathrm{Sb}$ & $\mathbf{V}$ & Co \\
\hline LM & 5.3 & 0.34 & 2.88 & $82 / 3 / 15$ & 22.6 & 817.3 & 9.7 & 465.5 & 123.6 & 16.6 & 1.81 & 13.9 & 9.6 & 109.8 & 10.8 \\
\hline LG & 5.0 & 1.40 & 4.96 & $83 / 2 / 15$ & 18.2 & 335.6 & 7.2 & 685.9 & 239.7 & 49.0 & 1.78 & 42.0 & 7.0 & 104.1 & 6.4 \\
\hline VA & 6.0 & 7.73 & 14.70 & $72 / 5 / 23$ & 38.7 & 1888.2 & 16.0 & 224.1 & 166.6 & 10.9 & 1.06 & 21.8 & 4.3 & 121.0 & 26.6 \\
\hline $\mathrm{CH}$ & 7.3 & 5.65 & 6.88 & $67 / 8 / 25$ & 32.0 & 977.5 & 11.9 & 52.2 & 144.7 & 18.9 & 0.64 & 19.9 & 1.0 & 107.8 & 12.9 \\
\hline \multicolumn{16}{|c|}{ Reference Soil Quality Standards } \\
\hline \multicolumn{5}{|c|}{ Canada [35] } & 87 & - & 50 & 91 & 360 & - & 22 & 600 & - & 130 & - \\
\hline \multicolumn{5}{|c|}{ Netherlands [37] } & 380 & - & 210 & 190 & 720 & 55 & 12 & 530 & 15 & 0 & 240 \\
\hline
\end{tabular}

${ }^{*}$ C.E.C. $=$ Cation exchange capacity. 
Comparing the trace element concentrations in the different structural parts of OP species, the levels found in the leaves were around 2-3 times lower than those measured in flower and leaves mixtures (Table 2, LG and LG leaves) in the same location, except for some elements. In this sense, $\mathrm{Cd}, \mathrm{Mn}$, and $\mathrm{Zn}$ concentrations were similar in both kinds of samples, which may suggest that these elements could be distributed more uniformly through the plant when their internal concentration is higher.

As a comparison with our study, we can mention the work in a $\mathrm{Pb}-\mathrm{Zn}$ mining area in Qingchengzi, China [38], where Oenothera biennis could simultaneously exclude the uptake of $\mathrm{Cd}$ and $\mathrm{Cu}$, having maximum plant concentration levels of $2.9\left(\mathrm{mg} \mathrm{kg}^{-1}\right)$ for $\mathrm{Cu}, 151.8\left(\mathrm{mg} \mathrm{kg}^{-1}\right)$ for $\mathrm{Zn}, 0.79\left(\mathrm{mg} \mathrm{kg}^{-1}\right)$ for $\mathrm{Cd}$, and $42.4\left(\mathrm{mg} \mathrm{kg}^{-1}\right)$ for $\mathrm{Pb}$. In a more recent study, plants of Oenothera sp. grown in a copper mining tailing area in Camaquã, Brazil [39], showed high ability to uptake $\mathrm{Cu}$ and $\mathrm{Cr}$ (196.2 and $15.9 \mathrm{mg} \mathrm{kg}^{-1}$, respectively) and this species was also highlighted for having good potential for phytoextraction of $\mathrm{Pb}$. Concerning the S. velutina (SV) species, critical copper concentrations were also found in this plant in LM, whereas chromium, nickel, and arsenic were found at toxic levels. Meanwhile, A. subfusiformis (AS) was the plant species with the lowest measured concentrations in LM, reaching concentration levels $80 \%$ lower (except for $\mathrm{Zn}$ ) than those found in OP species at the same location. Moreover, this plant species presented higher concentrations for chromium, manganese, and nickel in VA, reaching critical levels for $\mathrm{Cr}$ and toxic levels for Ni. These results are probably due to the higher concentration levels of these metals in VA in conjunction with the soil characteristics (Table 3). Similar results were found in abandoned red mud dumps (alumina refinery) in India [40], where high contents of $\mathrm{Ni}, \mathrm{Cd}$, and $\mathrm{Cr}\left(9.60,1.50\right.$, and $2.05 \mathrm{mg} \mathrm{kg}^{-1}$, respectively) were observed in plants from Argemone mexicana, and in other studies carried out in an industrial area of Riyadh City, Saudi Arabia, where A. mexicana was also highlighted as a good bioaccumulator of $\mathrm{Cr}$ and $\mathrm{Cd}[41,42]$.

A native plant from the genus Sphaeralcea has been described in studies in the United States of America, associated with desert environments in southeastern California [43] and an old uranium mine in Arizona [44]; Sphaeralcea ambigua showed concentrations of $\mathrm{Br}, \mathrm{Ca}$, $\mathrm{Ce}, \mathrm{Hf}, \mathrm{U}$, and $\mathrm{Zn}$ above the regional geometric mean value [43] and a bioconcentration factor for U of 0.051 [44].

The results of our work indicated that O. picensis (OP) and S. velutina (SV) species exhibited medium (200-600 $\mathrm{mg} \mathrm{kg}^{-1}$ ) accumulation of $\mathrm{Cu}$, in LM and LG for OP and in LM for SV, respectively. This is in agreement with the above-reported studies and the work developed initially in the IC [12], which identified OP species as the plants with the highest capacity for $\mathrm{Cu}$ accumulation. However, in our work, other results about additional trace elements and their concentrations in plants at different industrial-affected locations are provided, which underline the higher ability of OP species for elemental accumulation.

\subsection{Soil-to-Plant Transfer Factors for Trace Elements}

In order to better understand the role of soil and type of the contaminated area on the transfer of trace elements to these native plants, soil-to-plant transfer factor (TF) values for the 11 elements selected were calculated for each of the investigated plant species, as can be seen in Table 4. These TFs were determined using the average element concentrations found in plant species (Table 2) and soil samples (Table 3).

Table 4. Average transfer factor (TF) values of 11 TEs for the plant species collected at the different sampling locations. Los Maitenes (LM), La Greda (LG), Valle Alegre (VA), and yjr reference sampling point at Cachagua (CH). Underlined values indicate medium TF values (0.1-0.9), while those in bold indicate high TF values $(>1)$.

\begin{tabular}{|c|c|c|c|c|c|c|c|c|c|c|c|c|}
\hline Species & Location & $\mathrm{Cr}$ & Mn & $\mathrm{Ni}$ & $\mathrm{Cu}$ & $\mathrm{Zn}$ & As & $\mathrm{Cd}$ & $\mathrm{Pb}$ & $\mathrm{Sb}$ & V & Co \\
\hline \multirow{3}{*}{ O. picensis (OP) } & LM & 1.671 & $\underline{0.113}$ & 2.165 & 1.091 & $\underline{0.488}$ & 1.354 & $\underline{0.219}$ & 3.571 & $\underline{0.433}$ & $\underline{0.121}$ & $\underline{0.195}$ \\
\hline & LG & 1.371 & $\overline{0.360}$ & 2.394 & $\underline{0.582}$ & $\overline{0.492}$ & $\underline{0.245}$ & $\overline{0.177}$ & $\underline{0.285}$ & $\overline{0.264}$ & $\overline{0.078}$ & $\overline{0.233}$ \\
\hline & $\mathrm{CH}$ & 0.032 & 0.058 & $\underline{0.109}$ & $\underline{0.259}$ & $\underline{0.230}$ & 0.031 & 0.047 & 0.056 & 0.092 & 0.019 & 0.027 \\
\hline \multirow{2}{*}{ S. velutina (SV) } & LM & $\underline{0.939}$ & 0.088 & 1.381 & $\underline{0.763}$ & $\underline{0.555}$ & $\underline{0.825}$ & $\underline{0.237}$ & 1.329 & $\underline{0.216}$ & 0.037 & 0.097 \\
\hline & $\mathbf{C H}$ & $\overline{\underline{0.763}}$ & 0.069 & 1.225 & $\overline{0.284}$ & $\overline{0.231}$ & $\overline{0.026}$ & $\overline{0.191}$ & 0.055 & $\overline{0.101}$ & 0.008 & 0.036 \\
\hline \multirow{2}{*}{ A. subfusiformis (AS) } & LM & 0.306 & 0.032 & $\underline{0.512}$ & 0.078 & 0.371 & 0.092 & 0.041 & $\underline{0.456}$ & 0.029 & 0.005 & 0.021 \\
\hline & VA & $\overline{1.440}$ & 0.026 & $\overline{2.209}$ & 0.061 & $\underline{\underline{0.181}}$ & 0.030 & 0.073 & $\overline{0.090}$ & 0.018 & 0.003 & 0.033 \\
\hline
\end{tabular}


As it can be observed, TF values calculated for the different elements varied widely among the different plant species, ranging from 0.019 to 3.571 for O. picensis (OP), 0.008 to 1.381 for S. velutina (SV), and 0.003 to 2.209 for A. subfusiformis (AS). In general, $44 \%$ of TF values were in the medium- and $40 \%$ in the low-level range for most of the assayed elements, indicating a low uptake by plants compared to the soil reservoir (Table 4). Based on the 11 elements investigated, $\mathrm{Cr}, \mathrm{Ni}, \mathrm{Cu}$, As, and $\mathrm{Pb}$ had $\mathrm{TF}$ values $>1$, which indicated enrichment of these elements in plants in some locations.

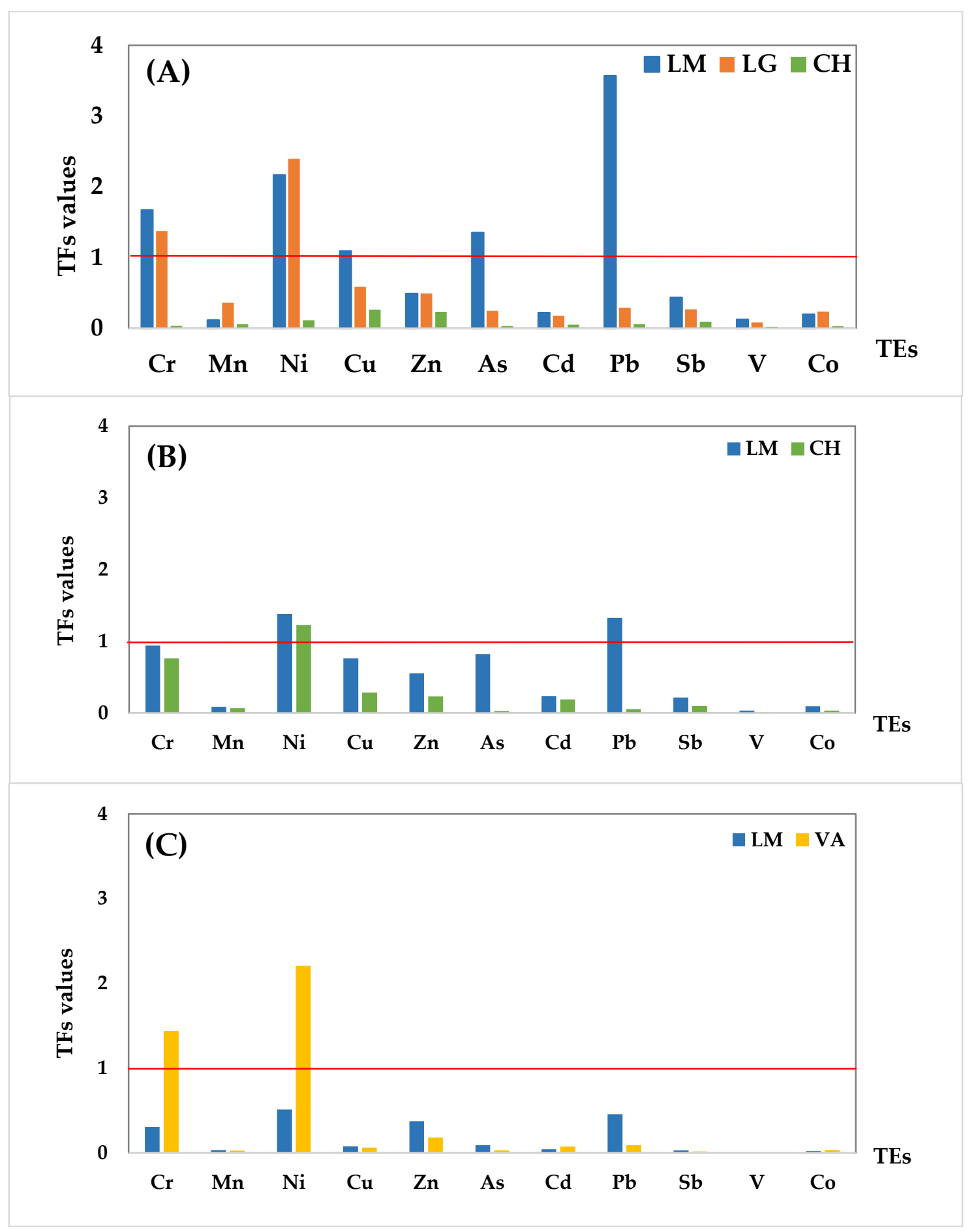

Figure 3. TF values for the 11 trace elements (TEs) at each sampling location according to the plant species: (A) O. picensis, (B) S. velutina, and (C) A. subfusiformis. The red line indicates $\mathrm{TF}=1$, the low limit for element enrichment. 
Figure 3A shows a general tendency for the TF values for most of the trace elements: $\mathrm{LM}>\mathrm{LG}>\mathrm{CH}$, except for $\mathrm{Mn}, \mathrm{Ni}$, and $\mathrm{Co}$, where the higher TF values in LG were not related to higher concentrations in soil. Concentrations in soil of $\mathrm{Cu}, \mathrm{Zn}, \mathrm{As}$, and V are above the guideline values for the world in at least one of the studied locations, as mentioned in Table 3 and by previous works in this area [10]. Regarding the present TF results, $\mathrm{O}$. picensis showed enrichment with $\mathrm{Pb}, \mathrm{Ni}, \mathrm{Cr}, \mathrm{As}$, and $\mathrm{Cu}$ (TFs $>1$ ), as well as potential enrichment with $\mathrm{Zn}$ (TFs $>0.5$ ), so this species can be selected as a native plant for phytoremediation in highly polluted soils, especially in acidic soils with very low organic matter content, such as LM soils.

Similarly, TF values obtained for the $S$. velutina species were above 1 for $\mathrm{Ni}(1.381)$ and $\mathrm{Pb}$ (1.329) in LM and only for Ni (1.225) in CH. As Figure 3B shows, TFs for all of the trace elements in LM were higher than those obtained for the $\mathrm{CH}$ location, which is positively related to the closeness of LM to the industrial complex and the high soil element concentrations. Considering the present TF results, S. velutina showed enrichment with $\mathrm{Pb}$ and $\mathrm{Ni}$ as well as potential enrichment with $\mathrm{Cr}$, As, $\mathrm{Cu}$, and $\mathrm{Zn}$ (TFs > 0.5), so this species can also be selected as a native plant for phytoremediation in highly polluted soils.

Figure $3 C$ illustrates the tendency in the TF values for the A. subfusiformis species. The transfer factors of all the elements were at the low and medium levels, except for $\mathrm{Ni}$ (2.209) and $\mathrm{Cr}$ (1.440) in VA. However, the TF values for $\mathrm{Ni}$ and $\mathrm{Pb}$ in $\mathrm{LM}$ show potential enrichment (TFs > 0.5). In the same way, A. mexicana showed a high TF for Ni (1.64) in the work of Gautam and Agrawal [40] in abandoned red mud dumps. According to these results, the ability of this species as a native plant is high enough to absorb $\mathrm{Ni}, \mathrm{Cr}$, and $\mathrm{Pb}$ in industrial areas.

Finally, it is worth mentioning that $\mathrm{V}$ was not accumulated in any plant species, even though its concentration in soil was higher than the guideline values mentioned in Table 3 and also by Salmanighabeshi et al. [10], suggesting a low bioavailability or an exclusion of this trace element in these plant species.

\section{Conclusions}

Three native plant species were collected in different locations around the industrial area of Puchuncaví-Ventanas, and the concentrations of 11 trace elements and their corresponding transfer factors were determined. Preliminary results showed a high concentration of trace elements in O. picensis, S. velutina, and A. subfusiformis species, which was inversely correlated to the distance of the primary emission sources, especially for those elements associated with industrial complex activities, such as $\mathrm{Cu}, \mathrm{As}, \mathrm{Cr}, \mathrm{Zn}, \mathrm{V}$, and $\mathrm{Ni}$.

The high concentrations of trace elements such as $\mathrm{Cu}, \mathrm{As}, \mathrm{Cr}$, and $\mathrm{V}$, close to the toxic limits in the native plant species of the industrial area, suggest the need for continuous monitoring of the region given that the area is under massive pressure from industrial activities. Nevertheless, no hyperaccumulator plants were found in any location. However, the results indicated that $O$. picensis, S. velutina, and A. subfusiformis species exhibited accumulation or potential accumulation for $\mathrm{Cu}, \mathrm{Pb}, \mathrm{As}, \mathrm{Ni}$, and $\mathrm{Cr}$ in the more industrial affected areas. O. picensis was identified as the plant with the highest capacity for TE accumulation.

Low bioavailability for $\mathrm{V}$ was evidenced by the low transfer factors obtained in most of the native plant species, despite the high soil concentration, suggesting the exclusion of this trace element.

In summary, this study provides preliminary baseline results on the element compositions of important native plants and soil in the Puchuncaví-Ventanas areas, which can serve as the basis for future resource management decisions concerning pollution assessment, plant toxicity and phytoremediation plans. 
Author Contributions: Conceptualization and methodology, S.S.-G., X.F.-R., E.P.-G., and F.C.-B.; validation, S.S.-G.; investigation, S.S.-G. and X.F.-R.; writing—original draft preparation, S.S.-G. and X.F.-R.; writing-review and editing, E.P.-G., F.C.-B., and C.M.-R.; supervision, E.P.-G. and F.C.-B.; project administration, E.P.-G. and F.C.-B.; funding acquisition, E.P.-G. and F.C.-B. All authors have read and agreed to the published version of the manuscript.

Funding: This work was funded by the Spanish Agency of International Cooperation for Development (AECID project A1/037813/11), Junta de Extremadura and FEDER (project IB-16114) and CETAM-UTFSM.

Data Availability Statement: Data is contained within the article.

Acknowledgments: Useful comments from Saioa Elcoroaristizábal are gratefully acknowledged.

Conflicts of Interest: The authors declare no conflict of interest. The funders had no role in the design of the study; in the collection, analyses, or interpretation of data; in the writing of the manuscript, or in the decision to publish the results.

\section{References}

1. Massa, N.; Andreucci, F.; Poli, M.; Aceto, M.; Barbato, R.; Berta, G. Screening for heavy metal accumulators amongst autochtonous plants in a polluted site in Italy. Ecotoxicol. Environ. Saf. 2010, 73, 1988-1997. [CrossRef] [PubMed]

2. Gorena, T.; Fadic, X.; Cereceda-Balic, F. Cupressus macrocarpa leaves for biomonitoring the environmental impact of an industrial complex: The case of Puchuncaví-Ventanas in Chile. Chemosphere 2020, 260, 127521. [CrossRef] [PubMed]

3. Ataabadi, M.; Hoodaji, M.; Afi, A. Heavy Metals Biomonitoring by Plants Grown in an Industrial Area of Isfahan' Mobarakeh Steel Company. J. Environ. Stud. 2010, 35, 83-92.

4. Baker, A.J.M.; McGrath, S.P.; Reeves, R.D.; Smith, J.A.C. Metal hyperaccumulator plants: A review of the ecology and physiology of a biological resource for phytoremediation of metal-polluted soils. In Phytoremediation of Contaminated Soils; Terry, N., Vangronsveld, J., Banuelos, G., Eds.; CRC Press: Boca Raton, FL, USA, 1999; pp. 85-107.

5. Mganga, N.; Manoko, M.L.K.; Rulangaranga, Z. Classification of plants according to their heavy metal content around North Mara Gold Mine, Tanzania: Implication for phytoremediation. Tanzan. J. Sci. 2011, 37, 109-119.

6. Del Río, M.; Font, R.; Almela, C.; Vélez, D.; Montoro, R.; De Haro Bailón, A. Heavy metals and arsenic uptake by wild vegetation in the Guadiamar river area after the toxic spill of the Aznalcóllar mine. J. Biotechnol. 2002, 98, 125-137. [CrossRef] [PubMed]

7. Zheng, N.; Wang, Q.; Zheng, D. Health risk of $\mathrm{Hg}, \mathrm{Pb}, \mathrm{Cd}, \mathrm{Zn}$, and $\mathrm{Cu}$ to the inhabitants around Huludao Zinc Plant in China via consumption of vegetables. Sci. Total Environ. 2007, 383, 81-89. [CrossRef] [PubMed]

8. Mihali, C.; Michnea, A.; Oprea, G.; Gogoasa, I.; Pop, C.; Marin Senilă, L.G. Trace element transfer from soil to vegetables around the lead smelter in Baia Mare, NW Romania. J. Food Agric. Environ. 2012, 10, 828-834.

9. Pastor, J.; Aparicio, A.M.; Gutierrez-Maroto, A.; Hernández, A.J. Effects of two chelating agents (EDTA and DTPA) on the autochthonous vegetation of a soil polluted with $\mathrm{Cu}, \mathrm{Zn}$ and Cd. Sci. Total Environ. 2007, 378, 114-118. [CrossRef]

10. Salmanighabeshi, S.; Palomo-Marín, M.; Bernalte, E.; Rueda-Holgado, F.; Miró-Rodríguez, C.; Fadic-Ruiz, X.; Vidal-Cortez, V.; Cereceda-Balic, F.; Pinilla-Gil, E. Long-term assessment of ecological risk from deposition of elemental pollutants in the vicinity of the industrial area of Puchuncaví-Ventanas, central Chile. Sci. Total Environ. 2015, 527-528, 335-343. [CrossRef]

11. Ginocchio, R. Effects of a copper smelter on a grassland community in the Puchuncaví Valley, Chile. Chemosphere 2000, 41, 15-23. [CrossRef]

12. González, I.; Muena, V.; Cisternas, M.; Neaman, A. Copper accumulation in a plant community affected by mining contamination in Puchuncaví valley, central Chile. Rev. Chil. Hist. Nat. 2008, 81, 279-291.

13. González, I.; Cortes, A.; Neaman, A.; Rubio, P. Biodegradable chelate enhances the phytoextraction of copper by Oenothera picensis grown in copper-contaminated acid soils. Chemosphere 2011, 84, 490-496. [CrossRef] [PubMed]

14. De Gregori, I.; Lobos, G.; Lobos, S.; Pinochet, H.; Potin-Gautier, M.; Astruc, M. Copper and selenium in rainwater, soils and alfalfa from agricultural ecosystems of Valparaiso region, Chile. Boletín la Soc. Chil. Química 2000, 45. [CrossRef]

15. Meier, S.; Alvear, M.; Borie, F.; Aguilera, P.; Cornejo, P. Different patterns of organic acid exudation in metallophyte and agricultural plants at increasing copper levels. In Proceedings of the the 19th World Congress of Soil Science; Soil Solutions for a Changing World; Gilkes, R., Prakongkep, N., Gilkes, R., Prakongkep, N., Eds.; International Union of Soil Sciences: Brisbane, Australia, 2010; pp. 17-20.

16. Muena, V.; González, I.; Neaman, A. Efectos del encalado y la fertilización nitrogenada sobre el desarrollo de Oenothera affinis en un suelo afectado por la minería del cobre. Rev. la Cienc. del suelo y Nutr. Veg. 2010, 10. [CrossRef]

17. Cochilco Anuario de Estadísticas del Cobre y Otros Minerales (1994-2013). Available online: https://biblioteca.cchc.cl/datafiles/ 33546-2.pdf (accessed on 13 December 2016).

18. AES Gener Principal. Available online: http://www.gener.cl/Paginas/Principal.aspx (accessed on 13 December 2016).

19. Folchi, D.M. Historia Ambiental de las Labores de Beneficio en la Minería del Cobre en Chile, Siglos XIX y XX; Universidad de Barcelona: Barcelona, Spain, 2006. 
20. Ginocchio, R.; Carvallo, G.; Toro, I.; Bustamante, E.; Silva, Y.; Sepúlveda, N. Micro-spatial variation of soil metal pollution and plant recruitment near a copper smelter in Central Chile. Environ. Pollut. 2004, 127, 343-352. [CrossRef]

21. González, I.; Neaman, A.; Rubio, P.; Cortés, A. Spatial distribution of copper and pH in soils affected by intensive industrial activities in Puchuncaví and Quintero, central Chile. J. Soil Sci. Plant Nutr. 2014. [CrossRef]

22. Parra, S.; Bravo, M.A.; Quiroz, W.; Moreno, T.; Karanasiou, A.; Font, O.; Vidal, V.; Cereceda, F. Distribution of trace elements in particle size fractions for contaminated soils by a copper smelting from different zones of the Puchuncaví Valley (Chile). Chemosphere 2014, 111. [CrossRef]

23. Tang, S.; Wilke, B.M.; Huang, C. The uptake of copper by plants dominantly growing on copper mining spoils along the Yangtze River, the People's Republic of China. Plant Soil 1999, 209, 225-232. [CrossRef]

24. Poschenrieder, C.; Bech, J.; Llugany, M.; Pace, A.; Fenés, E.; Barceló, J. Copper in plant species in a copper gradient in Catalonia (North East Spain) and their potential for phytoremediation. Plant Soil 2001, 230, 247-256. [CrossRef]

25. Wiseman, C.L.S.; Zereini, F.; Püttmann, W. Traffic-related trace element fate and uptake by plants cultivated in roadside soils in Toronto, Canada. Sci. Total Environ. 2013, 442, 86-95. [CrossRef]

26. Chojnacka, K.; Chojnacki, A.; Górecka, H.; Górecki, H. Bioavailability of heavy metals from polluted soils to plants. Sci. Total Environ. 2005, 337, 175-182. [CrossRef] [PubMed]

27. Kassaye, Y.A.; Skipperud, L.; Meland, S.; Dadebo, E.; Einset, J.; Salbu, B. Trace element mobility and transfer to vegetation within the Ethiopian Rift Valley lake areas. J. Environ. Monit. 2012, 14, 2698. [CrossRef] [PubMed]

28. Cheng, J.; Ding, C.; Li, X.; Zhang, T.; Wang, X. Heavy metals in navel orange orchards of Xinfeng County and their transfer from soils to navel oranges. Ecotoxicol. Environ. Saf. 2015, 122, 153-158. [CrossRef] [PubMed]

29. Zeng, F.; Ali, S.; Zhang, H.; Ouyang, Y.; Qiu, B.; Wu, F.; Zhang, G. The influence of $\mathrm{pH}$ and organic matter content in paddy soil on heavy metal availability and their uptake by rice plants. Environ. Pollut. 2011, 159, 84-91. [CrossRef] [PubMed]

30. Bakhat, H.F.; Zia, Z.; Abbas, S.; Hammad, H.M.; Shah, G.M.; Khalid, S.; Shahid, N.; Sajjad, M.; Fahad, S. Factors controlling arsenic contamination and potential remediation measures in soil-plant systems. Groundw. Sustain. Dev. 2019, 9, 100263. [CrossRef]

31. Shah, V.; Daverey, A. Phytoremediation: A multidisciplinary approach to clean up heavy metal contaminated soil. Environ. Technol. Innov. 2020, 18, 100774. [CrossRef]

32. Rueda-Holgado, F.; Palomo-Marín, M.R.; Calvo-Blázquez, L.; Cereceda-Balic, F.; Pinilla-Gil, E. Fractionation of trace elements in total atmospheric deposition by filtrating-bulk passive sampling. Talanta 2014, 125. [CrossRef]

33. Rueda-Holgado, F.; Calvo-Blázquez, L.; Cereceda-Balic, F.; Pinilla-Gil, E. A semiautomatic system for soluble lead and copper monitoring in atmospheric deposition by coupling of passive elemental fractionation sampling and voltammetric measurement on screen-printed gold electrodes. Microchem. J. 2016, 124. [CrossRef]

34. Rueda-Holgado, F.; Calvo-Blázquez, L.; Cereceda-Balic, F.; Pinilla-Gil, E. Temporal and spatial variation of trace elements in atmospheric deposition around the industrial area of Puchuncaví-Ventanas (Chile) and its influence on exceedances of lead and cadmium critical loads in soils. Chemosphere 2016, 144. [CrossRef]

35. CCME Canadian Soil Quality Guidelines for the Protection of Environmental and Human Health. Available online: https: / / www.esdat.net/environmental\%20standards/canada/soil/rev_soil_summary_tbl_7.0_e.pdf (accessed on 25 November 2020).

36. Australian Department of Environment and Conservation Assessment Level for Soil, Sediment and Water. Available online: https:/ / www.esdat.net/EnvironmentalStandards/Australia/WA/AssessmentLevels-2010.pdf (accessed on 18 September 2020).

37. Ministry of Housing Spatial Planning and the Environment (Netherlands) Circular on Target Values and Intervention Values for Soil Remediation. Available online: https://www.esdat.net/EnvironmentalStandards/Dutch/annexS_I200 ODutchEnvironmentalStandards.pdf (accessed on 12 September 2020).

38. Wei, S.; Zhou, Q.; Wang, X. Identification of weed plants excluding the uptake of heavy metals. Environ. Int. 2005, 31. [CrossRef]

39. Afonso, T.F.; Demarco, C.F.; Pieniz, S.; Quadro, M.S.; Camargo, F.A.O.; Andreazza, R. Bioprospection of indigenous flora grown in copper mining tailing area for phytoremediation of metals. J. Environ. Manag. 2020, 256. [CrossRef] [PubMed]

40. Gautam, M.; Agrawal, M. Identification of metal tolerant plant species for sustainable phytomanagement of abandoned red mud dumps. Appl. Geochem. 2019, 104. [CrossRef]

41. Al-Qahtani, K. Assessment of Heavy Metals Accumulation in Native Plant Species from Soils Contaminated in Riyadh City, Saudi Arabia. Life Sci. J. 2012, 9, 384-392.

42. Badr, N.; Fawzy, M.; Al-Qahtani, K. Phytoremediation: An ecological solution to heavy-metal-polluted soil and evaluation of plant removal ability. World Appl. Sci. J. 2012, 16, 1292-1301.

43. Chaffee, M.A.; Berry, K.H. Abundance and distribution of selected elements in soils, stream sediments, and selected forage plants from desert tortoise habitats in the Mojave and Colorado deserts, USA. J. Arid Environ. 2006, 67. [CrossRef]

44. Wetl, R.; Bensko-Tarsitano, B.; Johnson, K.; Sweat, K.G.; Cahill, T. Uptake of uranium into desert plants in an abandoned uranium mine and its implications for phytostabilization strategies. J. Environ. Radioact. 2020, 220-221, 106293. [CrossRef] 